\title{
Phytochemical analysis, antibacterial activity and antibiotic modifying action of Jatropha mollissima (Pohl.) Baill. (Euphorbiaceae)
}

Noelly Bastos-Cavalcante ${ }^{1}$, Cristina Rodrigues dos Santos-Barbosa ${ }^{2}$, Raimundo Luiz Silva-Pereira ${ }^{2}$, Débora Feitosa-Muniz ${ }^{2}$, Henrique Douglas de Melo-Coutinho², Larissa Araújo-Rolim ${ }^{1} \&$ Jackson Roberto Guedes da SilvaAlmeida ${ }^{1}$

1 Center for Studies and Research of Medicinal Plants, Federal University of San Francisco Valley, Petrolina-PE, Brazil.

2 Department of Biological Sciences, Regional University of Cariri, Crato-CE, Brazil.

\begin{abstract}
Resumen
Correspondence

N.B. Cavalcante

E-mail: lys.cavalcante@hotmail.com

Received: 2 January 2020

Accepted: 23 May 2020

Published on-line: 15 June 2020

Análisis fitoquímico, actividad antibacteriana y acción moduladora de antibióticos de Jatropha mollissima (Pohl.) Baill. (Euphorbiaceae)

La aparición de cepas bacterianas resistentes y los efectos secundarios de sus fármacos disponibles han hecho investigar nuevos compuestos antibacterianos bioactivos. Jatropha mollissima es una planta endémica del bioma Caatinga, Brasil. Existen informes en la literatura de que esta especie tiene acción antioxidante, antibacteriana y antiproliferativa. El presente estudio tuvo como objetivo evaluar el potencial antibacteriano y modulador de J. mollissima contra cepas bacterianas multirresistentes. El perfil fitoquímico se obtuvo por cromatografía de gases junto con espectrometría de masas. J. mollissima mostró actividad antibacteriana moderada y moduló la actividad del antibiótico Norfloxacino, promoviendo una relación antagonista. Este fue el primer estudio de este tipo realizado con J. mollissima.
\end{abstract}

Palabras clave: Jatropha mollissima; Euphorbiaceae; Actividad Antibacteriana; Terpenos.

\begin{abstract}
The emergence of resistant bacterial strains and the significant increase in side effects of currently available antibacterial drugs have made it urgent to develop research to identify new bioactives antibacterial compounds. Jatropha mollissima is a plant endemic to the Caatinga biome, Brazil and this species has antioxidant, antibacterial and antiproliferative action. The present study aimed to evaluate the antibacterial and modulatory potentials of J. mollissima against multiresistant bacterial strains. The phytochemical profile was obtained from gas chromatography coupled to mass spectrometry. J. mollissima presented moderate antibacterial activity and modulated the activity of the antibiotic Norfloxacin, promoting an antagonistic relationship. This was the first study of this nature carried out with $\mathrm{J}$. mollissima.
\end{abstract}

Key words: Jatropha mollissima, Euphorbiaceae, Antibacterial Activity, Terpenes. 


\section{Introduction}

In recent years, increasing microbial resistance to currently available antibiotics has become a serious public health problem, and the bacterial resistance, according to the World Economic Forum Global Risks, is considered to be one of the greatest threats to human health (Blair et al. 2015). Currently, several studies have been developed regarding the discovery of new antimicrobial agents from vegetable extracts and other natural products, with the objective of discovering new bioactive compounds with a livability compared to the traditional drugs, but with less toxicity and greater effectiveness against the resistance of pathogenic microorganisms, besides having a lower environmental impact (Al-Tohamy et al. 2018, Arulmozhi et al. 2018, Babahmad et al. 2018).

In Jatropha L. genus some plant species are already known to have antimicrobial properties and, in recent years, several studies have been carried out in different countries, demonstrating the effectiveness of plant extracts as antimicrobial agents (Félix-Silva et al. 2018; Hernandez-Hernandez et al. 2017, Rampadarath et al. 2016). In addition, many plant species have also been evaluated for their potential as resistance modulating agents (Calixto-Junior et al. 2015). Several chemical compounds obtained from natural sources have direct activity against many species of bacteria, increasing the activity of a specific antibiotic, reversing the natural resistance of these microorganisms and causing derangements in their mechanisms of resistance (Regueira-Neto et al. 2017). Potentiation of antibiotic activity or reversion of resistance to antibiotics allows the classification of these compounds as modulators of antibiotic activity (Coutinho et al. 2010).

Jatropha mollissima (Pohl.) Baill. is a plant popularly known as "pinhão-bravo", endemic to the Caatinga biome and widely distributed in the semiarid region of Brazil (Castro \& Cavalcante, 2011). There are reports in the literature that this species has antioxidant (Melo et al. 2010), antibacterial (Rocha \& Dantas, 2009) and antiproliferative (Dias et al. 2019) action. In this sense, this study aims to evaluate the antibacterial effect of J. mollissima extracts against Staphylococcus aureus Rosenbach 1884 and Pseudomonas aeruginosa (Schroeter 1872) Migula 1900 strains by determining the Minimum Inhibitory Concentration (MIC) and Minimum Bactericide Concentra- tion (MBC) using direct antibacterial activities, as well as its modulatory effect on standard antibiotics (amicacin, ampicillin and norfloxacin) in an attempt to discover new antimicrobial agents.

\section{Materials and methods}

\section{Bacterial samples}

Investigation of antibacterial activity: The bacterial strains utilized were Enterococcus faecalis (Andrewes \& Horder 1906) Schleifer \& KilpperBälz 1984 (ATCC 19433), Escherichia coli (Migula 1895) Castellani and Chalmers 1919 (ATCC 25922), Klebsiella pneumoniae (Schroeter 1886) Trevisan 1887(ATCC 13883), Salmonella enterica (ex Kauffmann \& Edwards 1952) Le Minor \& Popoff 1987 (ATCC 10708), Serratia marcescens Bizio 1823 (ATCC 13880), Shigella flexneri Castellani \& Chalmers 1919 (ATCC 12022) and Staphylococcus aureus (ATCC 25923). All strains were kept on slants with Müller-Hinton agar (MH, HIMEDIA). Before the assay, the cells were grown overnight at $37^{\circ} \mathrm{C}$ in brain heart infusion (BHI) broth (BHI, Difco Laboratories Ltda.).

Modulation of antibiotic activity: The bacterial strains utilized were the multiresistants clinical isolates $S$. aureus (SA358) and $P$. aeruginosa (PA03) with the source and resistance profile described in table 1. All strains were maintained on slants with heart infusion agar (HIA, Difco Laboratories Ltda.). Before the assay, the cells were grown overnight at $37^{\circ} \mathrm{C}$ in brain heart infusion (BHI) broth (BHI, Difco Laboratories Ltda.).

\section{Plant material}

Leaves of $J$. mollissima were collected in San Raimundo Nonato city, Piauí State, Brazil (Coordinates: 9०7'9132'S, 42 44'4716”'W). The botanical identification was obtained by comparing the samples collected with a voucher specimen deposited in the Herbario of San Francisco Valley (HVASF), of the Federal University of San Francisco Valley, (Petrolina, Pernambuco State, Brazil) as No. 23193.

\section{Preparation of J. mollissima extracts}

For the preparation of the extracts, leaves were collected and kept submersed in ethanol $95 \%$ for $72 \mathrm{~h}$. Afterwards, the extract was filtered and concentrated using a rotary vacuum evaporator 


\begin{tabular}{ccc}
\hline Bacteria & Origin & Resistance profile \\
\hline Staphylococcus aureus (SA358) & Surgical wound & Ca, Cep, Cp, Oxa, Pen, Amp, Amo, Clin, Mox, Cip, \\
Lsev, Asb, Ami, Eri, Cla, Azi. \\
Pseudomonas aeruginosa (PA03) & Catheter tip & Com, Ctz, Imi, Cip, Ptz, Lev, Mer, Ami. \\
\hline
\end{tabular}

Tabla 1. Origen bacteriano y perfil de resistencia. Ca: Cefadroxila; Cep: Cefalexina; Cf: cefalotina; Oxa: Oxacilina; Pen: Penicilina; Amp: Ampicilina; Amo: Amoxicilina; Clin: Clindamicina; Mox: Moxifloxacina; Cip: Ciprofloxacina; Lev: Levofloxacina; Asb: Ampicilina + Sulbactam; Ami: Amicacina; Eri: eritromicina; Cla: Claritromicina; Azi: Azitromicina; Com: Cefepima; Ctz: Ceftazidima; Imi: Imipenem; Ptz: Piperaciclina; Mer: Meropenem.

Table 1. Bacterial origin and resistance profile. Ca: Cefadroxil; Cep: Cephalexin; Cf: Cephalothin; Oxa: Oxacillin; Pen: Penicillin; Amp: Ampicillin; Amo: Amoxicillin; Clin: Clindamycin; Mox: Moxifloxacin; Cip: Ciprofloxacin; Lev: Levofloxacin; Asb: Ampicillin + Sulbactam; Ami: Amikacin; Eri: Erythromycin; Cla: Clarithromycin; Azi: Azithromycin; Com: Cefepime; Ctz: Ceftazidime; Imi: Imipenem; Ptz: Piperacycline; Mer: Meropenem.

\begin{tabular}{|c|c|}
\hline Phase & Yield \\
\hline Jm-Hex (hexane phase) & $8.54 \mathrm{~g}(10.67 \%)$ \\
\hline $\mathrm{Jm}-\mathrm{CHCl}_{3}$ (chloroform phase) & $15.45 \mathrm{~g}(19.31 \%)$ \\
\hline Jm-AcOEt (ethyl acetate phase) & $15.23 \mathrm{~g}(19.03 \%)$ \\
\hline $\mathrm{Jm}-\mathrm{MeOH}$ (methanolic phase) & $31.78 \mathrm{~g}(39.72 \%)$ \\
\hline Total & $71.00 \mathrm{~g}(88.73 \%)$ \\
\hline
\end{tabular}

Tabla 2. Rendimiento de las fases obtenidas por el proceso de fraccionamiento, por cromatografía líquida al vacío, del extracto etanólico crudo de J. mollissima (Jm-EEC).

Table 2. Yield of the phases obtained by the fractionation process by liquid chromatography under vacuum of the $J$. mollissima crude ethanolic extract (Jm-CEE).

(model Q-344B-Quimis, Brazil) and ultrathermal bath (model Q-214M2-Quimis, Brazil). The yield of crude ethanolic extract was approximately 100 g. Of the total of this material, $20 \mathrm{~g}$ was reserved for phytochemical analysis and biological tests. The remainder was subjected to the fractionation process using the liquid chromatography under vacuum technique. Silica gel was used as stationary phase and the solvents hexane, chloroform, ethyl acetate and methanol (in increasing polarity system) were used as mobile phase, aiming at a pre-fractionation of the substances through their polarities. For this purpose, $80 \mathrm{~g}$ of the crude ethanolic extract was adsorbed in a portion of the stationary phase with the aid of gral and pistil. Then, the phase separation process was carried out under vacuum (Saito et al. 2005). Obtaining yields of extracts presented in table 2. The solutions utilized in the tests was prepared at a concentration of $10 \mathrm{mg} / \mathrm{mL}$, dissolved in DMSO and then diluted with distilled water to obtain a concentration of $1024 \mu \mathrm{g} / \mathrm{mL}$.

\section{Phytochemical prospecting}

The phytochemical tests to detect the presence of alkaloids, anthocyanins, anthraquinones, phenolic compounds, coumarins, anthracene derivatives, lignans, mono, sesqui and diterpenes, naphthoquinones, saponins, hydrolyzable tannins, triterpenes and steroids were performed according to the method described by Oliveira et al. 2010 . These tests were based on the visual observation of a change in color or formation of precipitate after the addition of specific reagents, and the results for the extracts studied are shown in table 3 .

\section{Chemical characterization of J. mollissima by gas chromatography coupled to the mass spectrometer (GC-MS)}

The crude ethanolic extract was analyzed using the gas chromatography coupled to the mass spectrometer (GC-MS), in order to evaluate the chemical profile of the J. mollissima species. The substances present were investigated on a Shimadzu QP-2010 CG-EM apparatus. For the analyzes, the samples were resuspended in $10 \mathrm{mg} / \mathrm{mL}$ ethyl acetate (HPLC Grade) and then analyzed on a gas chromatograph coupled to a Shimadzu ${ }^{\circledR}$ mass spectrometer (QP-2010) equipped with a self-injector (AOC 20i). The following chromatographic conditions were employed: RESTEK ${ }^{\circledR}$ RTX-5MS column (30.0 $\mathrm{mm} \times 0.25 \mathrm{~mm} \times 0.25 \mathrm{~mm})$, using helium gas $(99.999 \%)$ transported with a constant flow of $1.4 \mathrm{~mL} / \mathrm{min}$, injection volume of the sample of $1.0 \mu \mathrm{L}$, split mode with ratio 5 (split 1:4 discard), injector temperature of $260{ }^{\circ} \mathrm{C}$, electron impact mode at $70 \mathrm{eV}$ and temperature of the ion source of $250{ }^{\circ} \mathrm{C}$. The furnace temperature was programmed to $80^{\circ} \mathrm{C}$ (isothermal for $3 \mathrm{~min}$ ), increasing from $5^{\circ} \mathrm{C} / \mathrm{min}$ to $285^{\circ} \mathrm{C}$ (isothermal for $15 \mathrm{~min}$ ) and $10^{\circ} \mathrm{C} / \mathrm{min}$ to $320^{\circ} \mathrm{C}$ (isothermal for $20 \mathrm{~min}$ ). A mixture of linear hydrocarbons (C9H20-C40H82) was injected under the same conditions as the samples under analysis, and the identification of the compounds was by comparison of the mass spectra obtained with the spectra 
presented by the equipment database (Wiley 7 and NIST $08 \mathrm{lib}$ ). The compound was considered as identified when it presented similarity index higher than or equal to $90 \%$.

\section{Drugs}

Gentamicin, amikacin, ampicillin and norfloxacin were obtained from Sigma Chemical Corp., St. Louis, MO, USA. All drugs were dissolved in sterile water to obtain the appropriate concentrations and decrease in toxicity.

\section{Extracts}

These leaf extracts of $J$. mollissima were used to test antibacterial efficiency: crude ethanolic extract (Jm-CEE), hexanic phase (Jm-Hex), chloroform phase $\left(\mathrm{Jm}-\mathrm{CHCl}_{3}\right)$, ethyl acetate phase (Jm$\mathrm{AcOEt})$ and methanolic phase (Jm-MeOH).

\section{Antibacterial test (minimal inhibitory con- centration and minimal bactericidal concen- tration)}

The antibacterial effect was determined by the broth microdilution method as recommended by The National Committee for Clinical Laboratory Standards (NCCLS, 2008). Initially, a $25 \mathrm{mg} / \mathrm{mL}$ stock solution of the extracts was prepared using a $20 \%(\mathrm{v} / \mathrm{v})$ aqueous solution of DMSO. One hundred microliters of this dilution were transferred to a microplate containing $100 \mu \mathrm{L}$ of Müller-Hinton broth. Serial dilutions were then performed, resulting in concentrations of $12.5,6.25,3.12$, $1.56,0.78,0.39,0.195$ and $0.0975 \mathrm{mg} / \mathrm{mL}$. The inoculums containing $5 \times 105 \mathrm{CFU} / \mathrm{mL}$, which corresponds to the 0.5 turbidity on the McFarland scale, were standardized by spectrophotometry, considering the interval between absorbance values of 0.08 to 0.1 . Subsequently, $10 \mu \mathrm{L}$ of these inoculums were added to each well. Wells were reserved in the microplates for control of broth sterility, bacterial growth and the actions of DMSO 20\% (negative control) and reference antimicrobial (gentamicin-positive control). For gentamicin, an initial concentration of $1.6 \mathrm{mg} / \mathrm{mL}$ was used, which was diluted to concentrations of $0.8,0.4,0.2,0.1,0.05,0.025$ and $0.0125 \mathrm{mg} / \mathrm{mL}$. The microplates were incubated under aerobic conditions for $24 \mathrm{~h}$ at $37{ }^{\circ} \mathrm{C}$ and afterwards $10 \mu \mathrm{L}$ of $2 \%$ 2,3,5-triphenyl-tetrazolium chloride (CTT) were added to each well for detection of the color change of CTT (colorless) to red, which reflects active bacterial metabolism. MIC was defined as the lowest concentration of the extract that visually inhibited bacterial growth. To determine the MBC, $10 \mu \mathrm{L}$ aliquots was removed from each well of the previous assay and transferred to Petri dishes containing Müller-Hinton agar. Plates were incubated for $24 \mathrm{~h}$ at $37{ }^{\circ} \mathrm{C}$. The appearance of bacterial colony for a given concentration indicates that it was not able to kill $99.9 \%$ or more of the bacterial inoculum used. The assays were performed in triplicate.

\section{Modulation of antibiotic activity}

Bacterial strains were maintained under ideal conditions of storage in HIA medium (Incline Heart Infusion; Difco Laboratories Ltd.). On the day before the start of the experiment, the bacterial samples were cultured and incubated under aerobic conditions for 24 hours at $37{ }^{\circ} \mathrm{C}$ in BHI medium (brain and heart infusion; Difco Laboratories Ltda). The inoculums containing $5 \times 105 \mathrm{CFU} / \mathrm{mL}$, corresponding to 0.5 turbidity on the McFarland scale, were standardized by spectrophotometry, considering the interval between absorbance values of 0.08 to 0.1 . In order to verify the modulatory activity of the samples Jm-CEE, Jm-Hex, Jm$\mathrm{CHCl}_{3}, \mathrm{Jm}-\mathrm{AcOEt}$ and $\mathrm{Jm}-\mathrm{MeOH}$, three antibiotics were considered standard in the treatment of infections promoted by the bacterial species tested: amikacin, ampicillin and norfloxacin. For the tests, antibiotic solutions were prepared at the initial concentration $1024 \mu \mathrm{g} / \mathrm{mL}$. Initially, the Minimum Inhibitory Concentration (MIC) experiment was performed, similarly to the previous topic, with serial dilutions $(1: 1)$ of the extracts, starting at the initial concentration of $1024 \mu \mathrm{g} / \mathrm{mL}$, resulting in the final concentrations of $512 ; 256$; $128 ; 64 ; 32 ; 16 ; 8 ; 4 ; 2 ; 1$ and $0.5 \mu \mathrm{g} / \mathrm{mL}$. The experiment was carried out in microculture plates, with 96 wells, the last reserved for sterility control. DMSO 20\% was used as negative control. A chromogenic indicator (Resazurin), which acts as an oxy-reduction indicator, a process that occurs in cellular respiration, in viable cells, was used to visualize whether or not there was growth of bacterial species. In the presence of these cells, the resazurin dye changes from dark blue to bright red, indicating which extracts concentrations were effective in inhibiting bacterial growth. The standard antibiotics (amikacin, ampicillin and norfloxacin) were used as controls, using the same initial concentration $(1024 \mu \mathrm{g} / \mathrm{mL})$ of the study samples (Coutinho et al. 2008). 


\section{Statistical analysis of microbiological re- sults}

The assays were performed in triplicates and results were expressed as average of replicates. The results are expressed as the geometric mean. TwoWay ANOVA was applied as Statistical hypothesis analysis using GraphPadPrism 6.0 software.

\section{Results}

\section{Phytochemical prospecting}

The preliminary phytochemical analysis carried out had the objective of detecting the main classes of secondary metabolites present in the $J$. mollissima extracts, comparing the profile found here with data present in the literature. The methodology used in this work allowed the investigation of twelve classes of secondary metabolites, suggesting the presence of important classes of these metabolites, varying in intensity depending on the sample (weak to strong). The results obtained with the preliminary study performed are described in table 3.

\section{Chemical characterization of $\mathrm{J}$. mollissima}

The analysis of the chemical composition of the crude ethanolic extract (Jm-CEE) obtained from the leaves of $J$. mollissima was performed using gas chromatography coupled to the mass spectrometer (GC-MS). The analysis revealed the presence of 51 peaks, as can be observed in the total ion chromatogram (TIC) shown in figure 1.

From 51 compounds detected, 23 constituents were identified as shown in table 4 . The Table lists the compounds, the retention time and their quantification in the crude ethanolic extract. Identification occurred by comparing the mass spectra of the compounds with the spectra of the databases present in the equipment.

Of the 23 constituents identified in the JmCEE, five constituents appeared in greater quantity: phytol (18.39\%), $\gamma$-Sitosterol (12.12\%), lupeol $(9.30 \%)$, linolenic acid $(6.09 \%)$ and $\beta$ amirin $(6.05 \%)$. Therefore, these were classified as major compounds. The chemical structures of these compounds are illustrated in figure 2 .

\section{Antibacterial tests (MIC and MBC)}

The results of the evaluation of the antibacterial effect of $J$. mollissima extracts are presented in Table 5 and are expressed as minimum inhibitory concentration (MIC) and minimum bactericidal concentration (MBC). According to the classification, it was possible to observe that among the results obtained for the minimum inhibitory concentration, the extracts $\mathrm{Jm}-\mathrm{CEE}$, Jm-Hex, $\mathrm{Jm}-\mathrm{CHCl}_{3}$ and Jm-AcOEt to the $S$. marcescens strain, presenting values of $0.195 ; 0.78 ; 0.78$ and $0.39 \mathrm{mg} /$ $\mathrm{mL}$, respectively. A good inhibitory activity of the $\mathrm{Jm}-\mathrm{CHCl}_{3}$ and $\mathrm{Jm}-\mathrm{AcOEt}$ phases against $E$. faecalis strain, with MIC values of 0.78 and $0.39 \mathrm{mg} /$ $\mathrm{mL}$ respectively, was also observed. Still, these same phases obtained a good result against the

\begin{tabular}{|c|c|c|c|c|c|}
\hline Chemical class & Jm-CEE & Jm-Hex & $\mathrm{Jm}-\mathrm{CHCl}_{3}$ & Jm-AcOEt & $\mathrm{Jm}-\mathrm{MeOH}$ \\
\hline 1 & + & + & - & - & - \\
\hline 2 & ++ & ++ & ++ & + & + \\
\hline 3 & +++ & +++ & + & - & - \\
\hline 4 & +++ & +++ & +++ & +++ & +++ \\
\hline 5 & +++ & + & + & - & - \\
\hline 6 & +++ & - & - & ++ & - \\
\hline 7 & + & - & - & + & + \\
\hline 8 & +++ & +++ & ++ & - & - \\
\hline 9 & - & - & - & - & - \\
\hline 10 & + & - & + & - & - \\
\hline 11 & +++ & - & - & +++ & + \\
\hline 12 & ++ & ++ & + & + & - \\
\hline
\end{tabular}

Tabla 3. Descripción de las clases de metabolitos secundarios investigados en extractos de J. mollissima. 1. Alcaloides 2. Antocianinas 3. Antraquinonas 4. Compuestos fenólicos 5. Cumarinas 6. Derivados antracénicos 7. Lignanos 8. Mono, sesqui y diterpenos 9. Naftoquinonas 10. Saponinas 11. Taninos y 12. Triterpenos / esteroles. Presencia de compuesto: (-) ausente, (+) débil, (++) moderado, (+++) fuerte. Jm-EEC (extracto etanólico crudo); $\mathrm{Jm}-\mathrm{Hex}$ (fase hexano); $\mathrm{Jm}_{-} \mathrm{CHCl}_{3}$ (fase cloroformo); Jm-AcOEt (fase acetato de etilo); $\mathrm{Jm}-\mathrm{MeOH}$ (fase metanólica).

Table 3. Description of the classes of secondary metabolites investigated in J. mollissima extracts. 1. Alkaloids 2 . Anthocyanins 3 . Anthraquinones 4. Phenolic compounds 5. Coumarins 6. Anthracenic derivatives 7. Lignans 8. Mono, sesqui and diterpenes 9. Naftoquinones 10. Saponins 11. Tannins and 12. Triterpenes/sterols. Presence of compound: $(-)$ absent, $(+)$ weak, $(++)$ moderate, $(+++)$ strong. Jm-CEE (crude ethanolic extract); Jm-Hex (hexane phase); Jm- $\mathrm{CHCl}_{3}$ (chloroform phase); Jm-AcOEt (ethyl acetate phase); Jm$\mathrm{MeOH}$ (methanolic phase). 


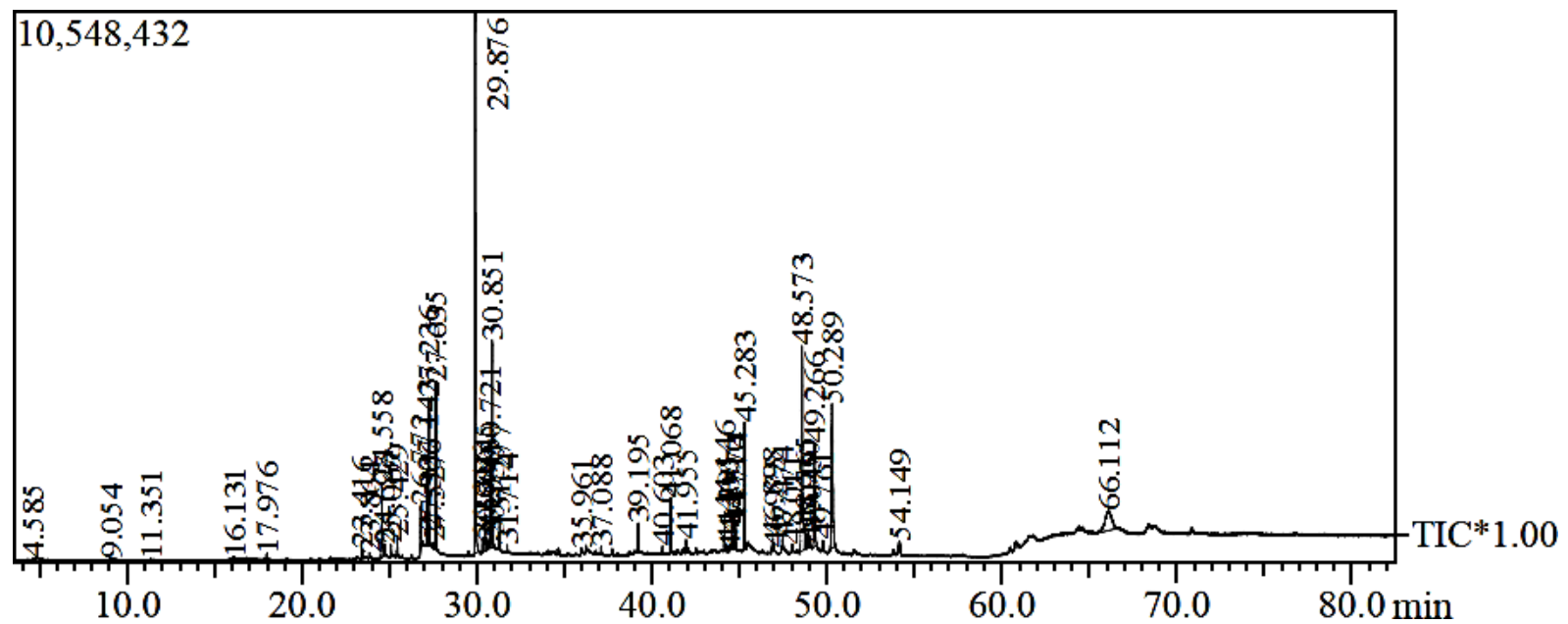

Figura 1. Cromatograma de iones totales del extracto etanólico crudo de J. mollissima.

Figure 1. Chromatogram of total ions of the crude ethanolic extract of J. mollissima.

\begin{tabular}{|c|c|c|c|c|c|c|c|c|c|}
\hline Peak & $\begin{array}{c}\mathrm{RT} \\
(\mathrm{min})\end{array}$ & Compound & $(\%)$ & $\mathbf{R} \mathbf{I}$ & Peak & $\begin{array}{c}\mathrm{RT} \\
(\mathrm{min})\end{array}$ & Compound & $(\%)$ & $\mathbf{R} \mathbf{I}$ \\
\hline 1 & 4.585 & $\mathrm{NI}$ & 0.19 & - & 27 & 35.960 & NI & 0.07 & - \\
\hline 2 & 9.055 & $\mathrm{NI}$ & 0.52 & - & 28 & 37.090 & 1,2-Benzenedicarboxylic acid (Phthalic & 0.20 & 2832 \\
\hline 3 & 11.350 & 3-Oxo-4-fenilbutironitrile & 0.29 & 1473 & & & acid) & & \\
\hline 4 & 16.130 & $\mathrm{NI}$ & 0.39 & - & 29 & 39.195 & n-pentacosane & 0.77 & 2500 \\
\hline 5 & 17.975 & $\mathrm{NI}$ & 0.22 & - & 30 & 40.605 & NI & 0.15 & - \\
\hline 6 & 23.415 & -(-) Loliolide & 0.56 & - & 31 & 41.070 & Esqualene & 1.55 & 2914 \\
\hline 7 & 23.865 & $\mathrm{NI}$ & 0.08 & - & 32 & 41.955 & n-tricosane & 0.33 & 2300 \\
\hline 8 & 24.560 & Neofitadiene & 2.59 & 1836 & 33 & 44.145 & $\mathrm{y}$-Tocoferol & 1.22 & 3036 \\
\hline 9 & 24.695 & NI & 0.46 & - & 34 & 44.295 & $\mathrm{NI}$ & 0.20 & - \\
\hline 10 & 25.070 & $\mathrm{NI}$ & 0.31 & - & 35 & 44.400 & $\mathrm{NI}$ & 0.77 & - \\
\hline 11 & 25.430 & $\mathrm{NI}$ & 0.66 & - & 36 & 44.710 & $\mathrm{NI}$ & 0.15 & - \\
\hline 12 & 26.770 & 9-hexadecenoic acid & 1.33 & 1976 & 37 & 44.775 & $N I$ & 0.91 & - \\
\hline 13 & 27.145 & Hexadecanoic acid & 2.51 & 1977 & 38 & 45.285 & $\alpha$-Tocoferol & 4.64 & 3149 \\
\hline 14 & 27.235 & Ethyl 9-hexadecenoate & 4.26 & 1986 & 39 & 46.900 & NI & 0.70 & - \\
\hline 15 & 27.305 & $\mathrm{NI}$ & 0.37 & - & 40 & 46.975 & $\mathrm{NI}$ & 0.02 & - \\
\hline 16 & 27.525 & NI & 0.17 & - & 41 & 47.475 & Stigmasterol & 0.51 & - \\
\hline 17 & 27.635 & Ethyl palmitate & 4.35 & 1993 & 42 & 48.010 & $\mathrm{NI}$ & 0.34 & - \\
\hline 18 & 29.875 & Phytol & 18.39 & 2045 & 43 & 48.575 & Y-Sitosterol & 12.12 & 2731 \\
\hline 19 & 30.315 & 9,12 octadecadienoic methyl ester acid & 0.53 & 2183 & 44 & 48.765 & $\mathrm{NI}$ & 1.25 & - \\
\hline 20 & 30.445 & $9,12,15$ octadecatrienoic methyl ester acid & 1.93 & 2191 & 45 & 48.930 & $\mathrm{NI}$ & 0.93 & - \\
\hline 21 & 30.580 & $\mathrm{NI}$ & 0.49 & - & 46 & 49.045 & NI & 0.36 & - \\
\hline 22 & 30.720 & Linoleic acid & 2.76 & 2193 & 47 & 49.265 & $\beta$-amirin & 6.05 & - \\
\hline 23 & 30.850 & Linolenic acid (omega 3) & 6.09 & 2201 & 48 & 49.760 & $N I$ & 0.53 & - \\
\hline 24 & 30.930 & $\mathrm{NI}$ & 0.24 & - & 49 & 50.290 & Lupeol & 9.30 & 2848 \\
\hline 25 & 31.275 & Ethyl stearate & 0.93 & 2198 & 50 & 54.150 & NI & 0.68 & - \\
\hline 26 & 31.715 & NI & 0.16 & - & 51 & 66.110 & $\mathrm{NI}$ & 5.72 & - \\
\hline
\end{tabular}

Tabla 4. Componentes químicos del extracto etanólico crudo de las hojas de J. mollissima. RT: Tiempo de retención; RI: Índice de retención, NI: No identificado.

Table 4. Chemical constituents of the crude ethanolic extract of the leaves of J. mollissima. RT: Retention time; RI: Retention index, NI: Not identified.

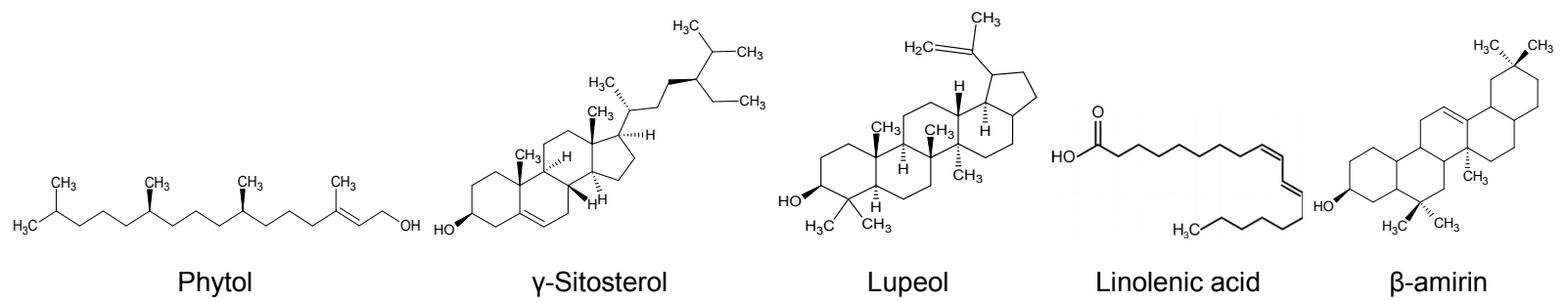

Figura 2. Estructuras químicas de los principales compuestos presentes en el extracto etanólico crudo de J. mollissima.

Figure 2. Chemical structures of the major compounds present in the crude ethanolic extract of J. mollissima. 


\begin{tabular}{|c|c|c|c|c|c|c|c|c|c|c|c|c|c|c|}
\hline \multirow{2}{*}{$\begin{array}{l}\text { Bacterial } \\
\text { strain }\end{array}$} & \multicolumn{2}{|c|}{ Jm-EEB } & \multicolumn{2}{|c|}{ Jm-Hex } & \multicolumn{2}{|c|}{$\mathrm{Jm}-\mathrm{CHCl}_{3}$} & \multicolumn{4}{|c|}{ Extract } & \multicolumn{2}{|c|}{$\begin{array}{c}\text { Positive control } \\
\text { (Gentamicin) }\end{array}$} & \multicolumn{2}{|c|}{$\begin{array}{c}\text { Negative } \\
\text { control } \\
\text { (DMSO) }\end{array}$} \\
\hline & MIC & MBC & MIC & MBC & MIC & MBC & MIC & MBC & MIC & MBC & MIC & MBC & MIC & MBC \\
\hline E. faecalis & 12.5 & - & 12.5 & - & 0.78 & - & 0.39 & - & 12.5 & - & 0.4 & 0.4 & - & - \\
\hline E. coli & 3.125 & 12.5 & 3.125 & 12.5 & 12.5 & 12.5 & 12.5 & 12.5 & - & - & * & 0.4 & - & - \\
\hline K. pneumoniae & 6.25 & - & - & - & 6.25 & - & - & - & - & - & 0.05 & 0.05 & - & - \\
\hline S. enterica & 12.5 & - & - & - & 6.25 & - & 12.5 & 12.5 & - & - & 0.05 & 0.05 & - & - \\
\hline S. marcescens & 0.195 & 12.5 & 0.78 & 12.5 & 0.78 & 12.5 & 0.39 & 12.5 & 12.5 & - & * & 0.025 & - & - \\
\hline S. flexneri & 3.125 & - & 6.25 & - & 3.125 & - & 0.195 & - & 12.5 & 12.5 & * & 0.025 & - & - \\
\hline S. aureus & 12.5 & - & 6.25 & - & 6.25 & - & 12.5 & - & - & - & 0.025 & 0.025 & - & - \\
\hline
\end{tabular}

Ratio MIC/MBC

\begin{tabular}{lccccccc}
\multicolumn{1}{c}{$\begin{array}{c}\text { Bacterial } \\
\text { strain }\end{array}$} & Jm-EEB & Jm-Hex & Jm-CHCl & Jm-AcOEt & Jm-MeOH & Gentamicin & DMSO \\
\cline { 2 - 8 } E. faecalis & - & - & - & - & - & 1 & - \\
E. coli & 4 & 4 & - & - & - & $*$ & - \\
K. pneumoniae & - & - & - & - & - & 1 & - \\
S. enterica & - & - & - & - & - & 1 & - \\
S. marcescens & 64 & 16 & 16 & 32 & - & $*$ & - \\
S. flexneri & - & - & - & - & - & 1 & - \\
S. aureus & - & - & - & - & - & Bactericide & Not effective
\end{tabular}

Tabla 5. Valores de concentración inhibitoria mínima (CIM) y concentración bactericida mínima (CBM) (mg/mL). Jm-CEE (extracto etanólico crudo); Jm-Hex (fase hexano); Jm-CHCl3 (fase cloroformo); Jm-AcOEt (fase acetato de etilo); Jm-MeOH (fase metanólica). (-) Ausencia de actividad en todas las concentraciones probadas; $(*)$ Sin crecimiento en todas las concentraciones probadas.

Table 5. Minimum inhibitory concentration (MIC) and minimum bactericidal concentration (MBC) values (mg/mL). Jm-CEE (crude ethanolic extract); Jm-Hex (hexane phase); Jm-CHCl3 (chloroform phase); Jm-AcOEt (ethyl acetate phase); Jm-MeOH (methanolic phase). (-) Absence of activity at all concentrations tested; $(*)$ No growth at all concentrations tested.

strain S. flexneri, with values of 3.125 and 0.39 $\mathrm{mg} / \mathrm{mL}$. Likewise, the crude ethanolic extract also obtained good inhibitory activity against $S$. flexneri, with a MIC $3.125 \mathrm{mg} / \mathrm{mL}$.

Regarding the minimum bactericidal concentration (MBC), all the extracts were weakly active, with $\mathrm{MBC}$ values higher or equal to 12.5 $\mathrm{mg} / \mathrm{mL}$ for all samples tested. However, as Biyiti et al. (2004), by means of the relationship between MIC and MBC values, a better evaluation of the antibacterial effect of bioactive compounds can be obtained. According to this author, a substance is considered to be bactericidal when the $\mathrm{MBC} / \mathrm{MIC}$ ratio is $\leq 2$ and bacteriostatic if the $\mathrm{MBC} / \mathrm{MIC}$ ratio is 2 . Based on these values, it was possible to classify the crude ethanolic extract and the hexane phase as having bacteriostatic effect against $E$. coli and $S$. marcescens, the chloroform phase as having a bacteriostatic effect against $K$. pneumoniae and $S$. marcescens, The ethyl acetate phase as having bacteriostatic effect against $S$. marcescens and the methanolic phase was classified as not effective for all bacterial strains tested. It was possible to observe that none of the extracts presented bactericidal potential against the bacterial strains tested.

\section{Direct antibacterial test (MIC) and modu- lation of antibiotic activity}

The Minimum Inhibitory Concentration (MIC) assay evaluated the direct $J$. mollissima extracts antimicrobial activity against $S$. aureus (SA358) and P. aeruginosa (PA03) strains. The MICs obtained are presented in table 6, where it is possible to observe the same MIC value obtained $(\geq 1024 \mu \mathrm{g} /$ $\mathrm{mL}$ ) against the two multiresistant strains (SA538 and PA03) tested. The high MIC values obtained for the samples tested and even for the antibiotics themselves can be attributed to the mechanisms of resistance that these two bacterial strains possess. Antibiotic resistance occurs when bacteria acquire genes that allow interference with the mechanism of action of the antibiotic (Loureiro et al. 2016).

There was no MIC reduction of the antibiotics for any of the samples tested (there was no synergistic interaction). The samples tested, in general, did not interfere with the effect of the antibiotics, with the exception of Norfloxacin. The antibiotic activity modulation of Norfloxacin by $J$. mollissima extracts against SA358 and PA03 can be seen in figure 3.

It was possible to observe an antagonistic 


\begin{tabular}{|c|c|c|}
\hline Substance & \multicolumn{2}{|c|}{ Bacterial strain } \\
\hline & $\begin{array}{l}\text { S. aureus } \\
\text { (SA358) }\end{array}$ & $\begin{array}{c}P . \text { aeruginosa } \\
\text { (PA03) }\end{array}$ \\
\hline Jm-CEE & $\geq 1024 \mu \mathrm{g} / \mathrm{mL}$ & $\geq 1024 \mu \mathrm{g} / \mathrm{mL}$ \\
\hline Jm-Hex & $\geq 1024 \mu \mathrm{g} / \mathrm{mL}$ & $\geq 1024 \mu \mathrm{g} / \mathrm{mL}$ \\
\hline $\mathrm{Jm}-\mathrm{CHCl}_{3}$ & $\geq 1024 \mu \mathrm{g} / \mathrm{mL}$ & $\geq 1024 \mu \mathrm{g} / \mathrm{mL}$ \\
\hline Jm-AcOEt & $\geq 1024 \mu \mathrm{g} / \mathrm{mL}$ & $\geq 1024 \mu \mathrm{g} / \mathrm{mL}$ \\
\hline Jm-MeOH & $\geq 1024 \mu \mathrm{g} / \mathrm{mL}$ & $\geq 1024 \mu \mathrm{g} / \mathrm{mL}$ \\
\hline Amicacin & $\geq 1024 \mu \mathrm{g} / \mathrm{mL}$ & $\geq 1024 \mu \mathrm{g} / \mathrm{mL}$ \\
\hline Ampicillin & $\geq 1024 \mu \mathrm{g} / \mathrm{mL}$ & $\geq 1024 \mu \mathrm{g} / \mathrm{mL}$ \\
\hline Norfloxacin & $\geq 512 \mu \mathrm{g} / \mathrm{mL}$ & $\geq 512 \mu \mathrm{g} / \mathrm{mL}$ \\
\hline
\end{tabular}

Tabla 6. Valores de concentración inhibitoria mínima (CIM). JmEEC (extracto etanólico crudo); Jm-Hex (fase hexono); Jm$\mathrm{CHCl} 3$ (fase cloroformo); Jm-AcOEt (fase acetato de etilo); Jm$\mathrm{MeOH}$ (fase metanólica).

Table 6. Minimum inhibitory concentration (MIC) values. JmCEE (crude ethanolic extract); Jm-Hex (hexane phase); Jm$\mathrm{CHCl} 3$ (chloroform phase); Jm-AcOEt (ethyl acetate phase); Jm$\mathrm{MeOH}$ (methanolic phase).

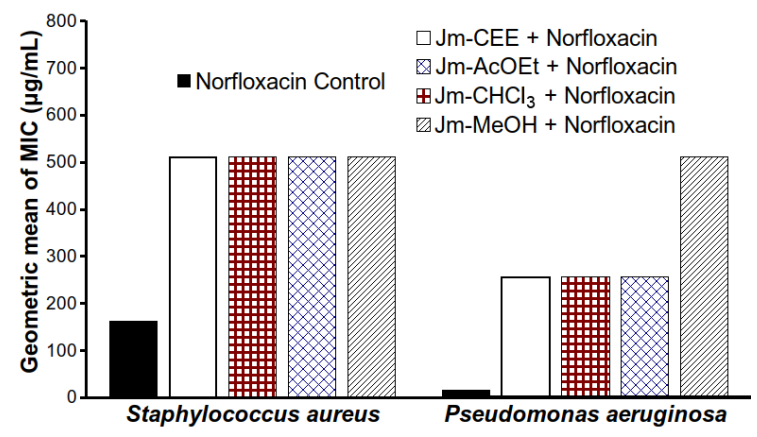

Figura 3. Efecto modulador de los extractos de $J$. mollissima (Jm-CEE, Jm-Hex, Jm-CHCl 3 , Jm-AcOEt y Jm-MeOH) en la actividad antibiótica del norfloxacino contra cepas resistentes a múltiples fármacos de $S$. aureus (SA358) y P. aeruginosa (PA03). Todos los extractos causaron efectos significativos en comparación con el control $(\mathrm{p}<0.0001)$.

Figure 3. Modulatory effect of extracts from J. mollissima (JmCEE, Jm-Hex, Jm- $\mathrm{CHCl}_{3}, \mathrm{Jm}-\mathrm{AcOEt}$ and $\mathrm{Jm}-\mathrm{MeOH}$ ) in the antibiotic activity of Norfloxacin against multidrug resistant strains of S. aureus (SA358) and P. aeruginosa (PA03). There were significant effects of all extracts with respect to the control $(\mathrm{p}<0.0001)$.

interaction (increase of antibiotic MIC) between the antibiotic Norfloxacin and all the samples tested. The crude ethanolic extract increased the MIC of the antibiotic from $16 \mu \mathrm{g} / \mathrm{mL}$ to $256 \mu \mathrm{g} /$ $\mathrm{mL}$ compared to the $P$. aeruginosa species and from $161 \mu \mathrm{g} / \mathrm{mL}$ to $512 \mu \mathrm{g} / \mathrm{mL}$ for $S$. aureus. The hexane phase, in turn, increased the MIC of the antibiotic from $16 \mu \mathrm{g} / \mathrm{mL}$ to $512 \mu \mathrm{g} / \mathrm{mL}$ compared to the P. aeruginosa species and from $161 \mu \mathrm{g} / \mathrm{mL}$ to $512 \mu \mathrm{g} / \mathrm{mL}$ for $S$. aureus. Chloroform and methanolic phases, as well as the crude ethanolic extract, increased the MIC of the antibiotic from $16 \mu \mathrm{g} / \mathrm{mL}$ to $256 \mu \mathrm{g} / \mathrm{mL}$ compared to the $P$. aeruginosa species and from $161 \mu \mathrm{g} / \mathrm{mL}$ to 512 $\mu \mathrm{g} / \mathrm{mL}$ for $S$. aureus. Finally, the ethyl acetate phase increased the MIC of the antibiotic from 16 $\mu \mathrm{g} / \mathrm{mL}$ to $645 \mu \mathrm{g} / \mathrm{mL}$ compared to the $P$. aeruginosa species and from $161 \mu \mathrm{g} / \mathrm{mL}$ to $512 \mu \mathrm{g} / \mathrm{mL}$ to $S$. aureus.

\section{Discussion}

Currently, several studies have been developed regarding the discovery of new antimicrobial agents from vegetable extracts and other natural products, with the objective of discovering new bioactive compounds with a hability compared to the traditional drugs, but with less toxicity and greater effectiveness against the resistance of pathogenic microorganisms, besides having a lower environmental impact. In the evaluation of the antimicrobial activity of plant extracts, different methods can be used, being the best known the method of diffusion in agar, disc-diffusion and methods of macrodilution and microdilution in broth (De Bona et al. 2014).

In the present study, it was possible to observe that $J$. mollissima acted as a moderate inhibitor against the species $S$. marcescens, E. faecalis and $S$. flexneri, probably due to the presence of phenolic compounds and terpenes in the chemical composition of the extracts (as was suggested in preliminary phytochemical screening). Thee substances present antimicrobial potential, as already reported in the literature. By means of the chromatographic analyzes by CG-MS it was possible to observe that the extracts analyzed present in their compositions different compounds of the class of terpenes. By observing the preliminary phytochemical profile, it was also possible to perceive that the crude ethanolic extract and its phases have in their composition these same constituents. Our work resembles a study by Rahman et al. (2014) with the Jatropha curcas L. species, in which metabolites such as 10-octadecenoic acid methyl ester, octadecanoic acid, 9,12-octadecadienoic acid methyl ester and $n$-hexadecenoic acid with antimicrobial potential were found.

Terpenes have aroused great interest due to the various biological activities already reported in the literature attributed to these compounds, such as anti-inflammatory, antibacterial, antifungal, antiviral, antitumor, antidiabetic, antiulcerogenic, hepatoprotective, neuroprotective, antiparasitic, analgesic and antioxidant (Coloma et al. 2011). In this sense, these metabolites may be associated with the antimicrobial activity presented by $J$. 
mollissima, because, according to studies, these have the ability to inhibit microbial growth. The mechanism of action responsible for its activity is not fully understood, but is probably due to disruption of the plasma membrane by its lipophilic compounds (Cowan 1999).

The use of plant extracts as antimicrobial agents minimizes the possibility of microorganisms becoming resistant to their action, since they are complex mixtures, making the microbial adaptability difficult. These natural compounds, when associated with certain antibiotics, may promote direct activity against various bacterial species, decreasing or increasing the activity of a specific antibiotic. The potentiation of antibiotic activity or the reversion of resistance to antibiotics allows the classification of these compounds as modulators of antibiotic activity (Coutinho et al. 2009).

\section{Acknowledgements}

This work was supported by Brazilian agency Foundation of Support to Science and Technology of the Pernambuco State (FACEPE).

\section{References}

Al-Tohamy R, Ali SS, Saad-Allah K, Fareed M, Ali A, ElBadry A, . . Rupani P F. 2018. Phytochemical analysis and assessment of antioxidant and antimicrobial activities of some medicinal plant species from Egyptian flora. Journal of Applied Biomedicine 16(4): 289-300. https://doi.org/10.1016/j.jab.2018. 08.001.

Arulmozhi P, Vijayakumar S \& Kumar T. 2018. Phytochemical analysis and antimicrobial activity of some medicinal plants against selected pathogenic microorganisms. Microbial Pathogenesis 123: 219-226. https://doi.org/10.1016/j.micpath.2018.07.009.

Babahmad RA, Aghraz A, Boutafda A. Papazoglou EG, Tarantilis PA, Kanakis C, . . . Ouhammou A. 2018. Chemical composition of essential oil of Jatropha curcas L. leaves and its antioxidant and antimicrobial activities. Industrial Crops and Products 121(1): 405-410. https://doi.org/10.1016/j. indcrop.2018.05. 030.

Behling EB, Sendão MC, Francescato HDC, Antunes L MG \& Bianchi MLP. 2004. Flavonoid quercetin: general aspects and biological actions. Alimentary Nutrition 15: 285-292.

Blair, JMA, Webber MA, Baylay AJ, Ogbolu DO \& Piddok LJV. 2015. Molecular Mechanisms of Antibiotic Resistance. Nature 13: 42-51. https://doi.org/10. 1038/nrmicro3380.

Calixto-Júnior JT, Morais SM, Vieira LG, Alexandre JB, Costa MS, Morais-Braga MFB, . . . Coutinho HDM.
2015. Phenolic composition and anticholinesterase, antioxidant, antifungal and antibiotic modulatory activities of Prockia crucis (Salicaceae) extracts collected in the Caatinga biome of Ceará State, Brazil. European Journal of Integrative Medicine 7(5): 547555. https://doi.org/ 10.1016/j.eujim.2015.04.006.

Castro AS and Cavalcante A. 2011. Flores da Caatinga. Instituto Nacional do Semiárido. Ministério da Ciência, Tecnologia e Inovação.

Coloma AG, Balboa CL, Reina OSM \& Fraga BM. 2011. Triterpene-based plant defenses. Phytochemistry Reviews 10: 245-260. https://doi.org/10.1007/s111 01-010-9187-8.

Coutinho HDM, Costa JGM, Lima OE, Falcão-Silva V \& Siqueira-Júnior JP. 2008. Enhancement of the antibiotic activity against a multiresistant Escherichia coli by Mentha arvensis L. and chlorpromazine. Chemotherapy 54(4): 328-330. https://doi.org/10.3109/13 880200902991540.

Coutinho HDM, Costa JGM, Lima OE, Falcão-Silva V \& Siqueira-Júnior J P. 2009. In vitro interference of Momordica charantia in the resistance to aminoglycosides. Pharmaceutical Biology (47:11): 1056-1059.

Coutinho HDM, Costa, JGM, Lima EO \& Siqueira-Júnior JP. 2010. Effect of Momordica charantia L. in the resistance to aminoglycosides in methicilin-resistant Staphylococcus aureus. Comparative Immunology, Microbiology and Infectious Diseases 33(6):467-471. https://doi.org/10.1016/j.cimid.2009. 08.001.

Coutinho HDM, Silva I, Freitas MA, Gondim CNFL \& Andrade J C. 2013. Análise físico-química e avaliação antimicrobiana do fruto cambuí (Myrcia multiflora). Revista de Biologia, Farmácia e Manejo agrícola 9(1): 96-103.

Cowan MM. 1999. Plant products as antimicrobial agents. Clinical Microbiology Reviews 12: 564-582. https://doi.org/10.1128/CMR.12.4.564.

De Bona EAM, Pinto FGS, Fruet TK, Jorge TCM \& Moura AC. 2014. Comparação de métodos para avaliação da atividade antimicrobiana e determinação da concentração inibitória mínima (CIM) de extratos vegetais aquosos e etanólicos. Arquivos do Instituto Biológico 81(3): 218-225. https://doi.org/10. 1590/1808-1657001192012.

Dias WLF, Do Vale-Junior EP, Oliveira MDA, Barbosa YLP, Silva JN, Costa-Júnior JS, . . Martins F A. 2019. Cytogenotoxic effect, phytochemical screening and antioxidant potential of Jatropha mollissima (Pohl) Baill leaves. South African Journal of Botany 123: 30-35. https://doi.org/10.1016/j.sajb.2019.02. 007.

Félix-Silva J, Gomes JAS, Fernandes JM, Moura AKC, Menezes YAS, Santos ECG, . . . Fernandes-Pedrosa MF. 2018. Comparison of two Jatropha species (Euphorbiaceae) used popularly to treat snakebites in Northeastern Brazil: Chemical profile, inhibitory activity against Bothrops erythromelas venom and antibacterial activity. Journal of Ethnopharmacology 213: 12-20. https://doi.org/10.1016/j.jep.2017. 11.002.

Granowitz EV \& Brown RB. 2008. Antibiotic adverse reactions and drug interactions. Critical Care Clinics 24: 421-442. https://doi.org/10.1016/j.ccc.2007.12.0 11. 
Hernández-Hernández AB, Alarcón-Aguilar FJ, Almanza-Pérez JC Nieto-Yáñez O, Olivares-Sánchez JM, Durán-Díaz A., . . . Canales-Martínez MM 2017. Antimicrobial and anti-inflammatory activities, wound-healing effectiveness and chemical characterization of the latex of Jatropha neopauciflora Pax. Journal Ethnopharmacological 23: 1-7. https://doi. org/10.1016/j.jep.2017.04.003.

Hoefler R \& Wannmacher L. 2010. Interações de Medicamentos. In: Brasil. Ministério da Saúde. Secretaria de Ciência, Tecnologia e Insumos Estratégicos. Departamento de Assistência Farmacêutica e Insumos Estratégicos. Brasília (DF), pp. 1-14.

Loureiro RJ, Roque F, Rodrigues AT, Herdeiro MT \& Ramalheira H. 2016. O uso de antibióticos e as resistências bacterianas: breves notas sobre a sua evolução. Revista Portuguesa de Saúde Pública 34(1): 77-84. https://doi.org/10.1016/j.rpsp.2015.11. 003.

Mahan LK, Escott-Stump S \& Raymond JL. 2012. Krause: alimentos, nutrição e dietoterapia. Rio de Janeiro-RJ: Elsevier.

Melo JG, Araújo TAS, Castro VTNA, Cabral LVD, Desterro MR, Nascimento SN, . . Albuquerque U P. 2010. Antiproliferative activity, antioxidant capacity and tannin content in plants of semi-arid northeastern Brazil. Molecules 15: 8534-8542. https://doi. org/ 10.3390/molecules15128534.

NCCLS - National Comitee for Clinical Laboratory Standards. 2008. Methods for dilution antimicrobial susceptibility tests for bacteria that grow aerobically: Approved standard. 6th ed. NCCLS document M7A6. National Committee for Clinical Laboratory Standards, Wayne, USA.

Oliveira F, Ritto JLA, Akisue G \& Bacchi EM. 2010. Fundamentos de cromatografia aplicada a fitoterápicos. São Paulo: Ed. Atheneu.

Rahman MM, Ahmad SH, Mohamed MTM \& Ab Rah- man MZ. 2014. Antimicrobial Compounds from Leaf Extracts of Jatropha curcas, Psidium guajava, and Andrographis paniculata. The Scientific World Journal 2014(635240): [8] https://doi.org/10.1155/ 2014/635240.

Rampadarath S, Puchooa D \& Jeewon R. 2016. Jatropha curcas L: Phytochemical, antimicrobial and larvicidal properties. Asian Pacific Journal of Tropical Biomedicine 6(10): 858-865. https://doi.org/10.1016/ j.apjtb.2016.01.019.

Regueira-Neto MS, Tintino SR, Silva ARP, Costa MS, Boligon AA, Matias EFF, . . . Coutinho HDM. 2017. Seasonal variation of Brazilian red propolis: Antibacterial activity, synergistic effect and phytochemical screening. Food and Chemical Toxicology 107: 572580. https://doi.org/10.1016/j.fct.2017.03.052.

Rocha FAG \& Dantas LIS. 2009. Atividade antimicrobiana in vitro do látex do aveloz (Euphorbia tirucalli L.), pinhão bravo (Jatropha mollissima L.) e pinhão roxo (Jatropha gossypiifolia L.) sobre microrganismos patogênicos. Holos 4: 3-11. https://doi.org/10.15628/ holos. 2009.339

Saito E, Furlan C, Lopes GC \& Mello J C P. 2005. A cromatografia líquida a vácuo na análise qualitativa $e$ quantitativa de flavonoides em Achyrocline satureioides. Revista Fitos 1: 57-59.

Saraiva RMC. 2012. Atividade antibacteriana de plantas medicinais frente à bactérias multirresistentes e a sua interação com drogas antimicrobianas. Mestrado em Ciências Farmacêuticas, Universidade Federal do Pará. Masters dissertation.

Veras HNH, Santos IJM, Santos ACB, Fernandes CM, Matias EFF, Leite GO,. . . Coutinho H D M. 2011. Comparative evaluation of antibiotic and antibiotic modifying activity of quercetin and isoquercetin in vitro. Current topics in nutraceutical research 9: 2530. 